\title{
THE OCCURRENCE AND SEX RATIO \\ OF DIABRoticA VIRGIFERA LE CONTE BEETLES \\ ON SWEET MAIZE (ZEA MAYS VAR. SACCHARATA) \\ IN SOUTH-EASTERN POLAND NEAR RZESZÓW IN 2007-2009
}

\author{
Paweł K. BEREŚ ${ }^{1}$, Rafał SIONEK ${ }^{2}$ \\ ${ }^{1}$ Institute of Plant Protection + National Research Institute \\ Regional Experimental Station \\ Langiewicza 28, 35-101 Rzeszów, Poland \\ ${ }^{2}$ Plant Health and Seed Inspection Service, Voivodeship Inspectorate \\ Langiewicza 28, 35-101 Rzeszów, Poland
}

Received: February 6, 2009; Accepted: August 9, 2010

\begin{abstract}
Summary
Studies were conducted in 2007-2009 on sweet maize (Zea mays var. saccharata), Candle variety, in Terliczka near Rzeszów. The observations were carried out based on an permission from the Main Inspectorate of Plant Health and Seed Inspection, No. WF-411d/5/2008.

The objective of the conducted study was to specify the occurrence dynamics of Western corn rootworm (WCR) (Diabrotica virgifera) beetles on sweet maize in order to establish the optimal period for their control. In addition their sexual structure between July and September were specified.

In south-eastern Poland $D$. virgifera beetles began their flights onto sweet maize plants from the second decade of July. Male occurred first, and the flights of females began several days later. Moreover, it was found that the maximum number of males on plants is recorded earlier than that of females.

During the feeding of beetles on maize the period of their most abundant occurrence was from the end of July to the third decade of August. During the flight of adult one population peak was usually recorded: in the third decade of July and the first decade of August, and only in 2007 was it in the second decade of July. In 2007-2009, D. virgifera ended their feeding in late September.

Females dominated among the captured insects during the study years. Their percentage share in the total number of captured beetles was from 59.7 to $84.1 \%$. The population of males in individual years varied, and their percentage share was between 15.9 and $40.3 \%$.
\end{abstract}

key words: Diabrotica virgifera, sweet maize, occurrence, sex ratio

Corresponding author:

e-mail: p.beres@iorpib.poznan.pl

(C) Copyright by RIVC 


\section{INTRODUCTION}

The Western corn rootworm (Diabrotica virgifera Le Conte) is one of the most dangerous maize pests worldwide. Owing to high losses in the yields of this plant caused by the feeding of larvae and beetles, its ability of active and passive long-distance migration, high fertility and the risk to environmental biodiversity, this species has been classified in the European Union as a quarantine pest and is compulsorily controlled in the area of the European Community (Konefał \& Bereś 2009).

The WCR is not a native European species. It was brought accidentally from North America to Serbia in the 1980 (Bača 1994). Later on, the pest was independently introduced from the USA in several other places on the European continent (Ciosi et al. 2008). From the first official detection of the WCR in Serbia up to the end of 2009 this pest was recorded in 20 European countries (EPPO 2010).

In Poland $D$. virgifera has been recorded since 2005 (Sahajdak et al. 2006 a,b). Initially, it was only found in the south-eastern part of Poland in Podkarpackie province, but in the next few years it dispersed across almost the entirety of southern Poland (Konefał et al. 2007, Konefał \& Bereś 2009). Up to the end of 2009 it was recorded in 8 provinces: Podkarpackie, Lubelskie, Małopolskie, Świętokrzyskie, Mazowieckie, Śląskie, Opolskie and Dolnośląskie.

Owing to the short period of $D$. virgifera occurrence in Poland, a complex plan for the protection of maize against this pest has not yet been developed, because studies on the biology of this species, including periods of occurrence of individual developmental stages under Polish soil and climate conditions have not yet been completed.

Currently, the dominant development stage of the WCR in Poland is the beetle stage, and therefore, since 2006, the Institute of Plant Protection-NRI has been conducting studies on their occurrence on maize, including sweet maize (Zea mays var. saccharata). Knowledge of the periods in which beetles occur, especially females, which by depositing eggs give a start to a new pest generation in the following vegetation season, allows for the prediction of the period in which chemical control interventions should be performed.

The objective of the conducted study was to specify the occurrence dynamics of $D$. virgifera beetles on sweet maize in order to establish an optimal period for their control, and to specify their sexual structure.

\section{MATERIALS AND METHODS}

Studies were conducted on sweet maize, Candle variety, in 2006-2009 in Terliczka, near Rzeszów. Because the WCR is a quarantine pest, the observations were carried out based on an permission from the Main Inspectorate of Plant Health and Seed Inspection Service, No. WF411d/5/2008.

Maize was cultivated in a monoculture under the supervision of the State Plant Health and Seed Inspection Service (SPHSIS). The plants in the study years were sown at the same time, in the first decade of May.

To establish the occurrence dynamics of beetles on maize, starting 
from mid-June, when the plants were at development stage $\mathrm{BBCH}$ 31-33 (Adamczewski \& Matysiak 2002) until the end of their vegetation, a regular, 2-3 times a week careful inspection was carried out on 100 consecutive plants diagonally in a row in five places of cultivation (in total 500 plants). All above-ground plant parts, i.e. tassels, stems, leaf blades and cobs, were inspected for the presence of beetles. Observations were carried out in the evening after $6 \mathrm{pm}$, when the activity of beetles was the highest.

As an auxiliary method for detection of the first low number of $D$. virgifera beetles leaving the pupa, pheromone traps were used (PAL model with a Hungarian pheromone, Csalomon). Two pheromone traps for capturing male WCR were placed in the field in the last decade of June. They were placed at a 30-meter distance in a margin strip of the maize field (in the $10^{\text {th }}$ row) and inspected on a regular basis, 2-3 times a week. The traps were removed at the moment when the first beetles were detected on plants or in pheromone traps, and further analysis concerned only plant observation.

Individuals observed on the plants were collected in containers and poisoned with ethyl acetate. After being transported to a laboratory, they were classified according to species and sex based on available literature (Krysan \& Smith 1987, EPPO 2004).

Changing weather parameters were recorded during the study and they had a potential effect on the changing population of $D$. virgifera beetles present on plants. Changes in average daily temperatures and rainfall in a decade period over the vegetation season of sweet maize in 2007-2009 are presented in Table 1.

Weather conditions in 2007 were favourable to both maize cultivation and the development of $D$. virgifera larvae. Despite low temperatures and intense rainfall in the first half of May, followed by short periods of drought, plants germinated evenly, and the development of seedlings and juvenile plants was undisturbed. Later on (from July) warm and relatively wet weather, with periods of very high temperatures, significantly accelerated plant vegetation in the study area by about 2-3 weeks. Such weather conditions were favourable to the beetles of $D$. virgifera, whose activity was the highest during warm days.

In 2008, directly after maize sowing, there were periods with low temperature as well as intense rainfall, which inhibited plant growth. From June the weather improved and the development of maize accelerated. Changes in weather conditions in 2008, particularly the low number of days with high temperatures and prolonged precipitation, were factors limiting the activity of $D$. virgifera beetles.

In 2009 weather conditions in the south-eastern part of Poland were highly diversified. In the first half of May a prolonged drought was observed which delayed sowing as well as the growth of already germinated plants. In the later period, relatively low temperatures and intense rainfall slowed down plant development. Weather conditions began to improve from mid-June. The summer was moderately hot, relatively dry, with a low number of rainy days. 
Table 1. Weather conditions in 2007-2009 in Terliczka

\begin{tabular}{|c|c|c|c|c|c|c|}
\hline \multirow{2}{*}{ Year } & \multirow{2}{*}{ Months } & \multirow{2}{*}{ Weather parameters } & \multicolumn{3}{|c|}{ decade period } & \multirow{2}{*}{$\begin{array}{c}\text { Mean } \\
\text { or sum } \\
\text { in month }\end{array}$} \\
\hline & & & $\mathrm{I}$ & II & III & \\
\hline \multirow[t]{10}{*}{2007} & \multirow[t]{2}{*}{ May } & Daily average air temperature $\left({ }^{\circ} \mathrm{C}\right)$ & 10.4 & 16.1 & 19.9 & 15.4 \\
\hline & & Rainfall sum $(\mathrm{mm})$ & 15.8 & 17.4 & 6.7 & 39.9 \\
\hline & \multirow[t]{2}{*}{ June } & Daily average air temperature $\left({ }^{\circ} \mathrm{C}\right)$ & 18.6 & 20.4 & 17.7 & 18.9 \\
\hline & & Rainfall sum (mm) & 28.4 & 13.7 & 28.4 & 70.5 \\
\hline & \multirow[t]{2}{*}{ July } & Daily average air temperature $\left({ }^{\circ} \mathrm{C}\right)$ & 17.5 & 21.8 & 20.4 & 19.9 \\
\hline & & Rainfall sum (mm) & 40.0 & 19.3 & 14.3 & 73.6 \\
\hline & \multirow[t]{2}{*}{ August } & Daily average air temperature $\left({ }^{\circ} \mathrm{C}\right)$ & 18.2 & 19.3 & 19.5 & 19.0 \\
\hline & & Rainfall sum (mm) & 36.8 & 51.1 & 0.0 & 87.9 \\
\hline & \multirow[t]{2}{*}{ September } & Daily average air temperature $\left({ }^{\circ} \mathrm{C}\right)$ & 12.8 & 12.0 & 12.7 & 12.5 \\
\hline & & Rainfall sum (mm) & 115.6 & 18.5 & 7.6 & 141.7 \\
\hline \multirow[t]{10}{*}{2008} & \multirow[t]{2}{*}{ May } & Daily average air temperature $\left({ }^{\circ} \mathrm{C}\right)$ & 11.3 & 14.7 & 14.4 & 13.4 \\
\hline & & Rainfall sum (mm) & 30.3 & 45.6 & 29.4 & 105.3 \\
\hline & \multirow[t]{2}{*}{ June } & Daily average air temperature $\left({ }^{\circ} \mathrm{C}\right)$ & 17.9 & 16.2 & 19.7 & 17.9 \\
\hline & & Rainfall sum (mm) & 1.4 & 40.0 & 45.3 & 86.7 \\
\hline & \multirow[t]{2}{*}{ July } & Daily average air temperature $\left({ }^{\circ} \mathrm{C}\right)$ & 17.8 & 19.2 & 19.0 & 18.6 \\
\hline & & Rainfall sum (mm) & 35.9 & 43.3 & 38.4 & 117.6 \\
\hline & \multirow[t]{2}{*}{ August } & Daily average air temperature $\left({ }^{\circ} \mathrm{C}\right)$ & 19.6 & 19.2 & 17.3 & 18.9 \\
\hline & & Rainfall (mm) & 21.2 & 18.2 & 15.9 & 55.3 \\
\hline & \multirow[t]{2}{*}{ September } & Daily average air temperature $\left({ }^{\circ} \mathrm{C}\right)$ & 19.3 & 9.0 & 10.7 & 13.0 \\
\hline & & Rainfall sum (mm) & 5.0 & 84.1 & 14.1 & 103.2 \\
\hline \multirow[t]{10}{*}{2009} & \multirow[t]{2}{*}{ May } & Daily average air temperature $\left({ }^{\circ} \mathrm{C}\right)$ & 12.6 & 13.5 & 14.6 & 13.6 \\
\hline & & Rainfall sum (mm) & 1.6 & 56.0 & 45.0 & 102.6 \\
\hline & \multirow[t]{2}{*}{ June } & Daily average air temperature $\left({ }^{\circ} \mathrm{C}\right)$ & 14.9 & 15.2 & 17.3 & 15.9 \\
\hline & & Rainfall sum (mm) & 17.8 & 60.9 & 50.7 & 137.5 \\
\hline & \multirow[t]{2}{*}{ July } & Daily average air temperature $\left({ }^{\circ} \mathrm{C}\right)$ & 20.0 & 20.1 & 19.8 & 20.0 \\
\hline & & Rainfall sum $(\mathrm{mm})$ & 63.4 & 9.0 & 23.6 & 96.0 \\
\hline & \multirow[t]{2}{*}{ August } & Daily average air temperature $\left({ }^{\circ} \mathrm{C}\right)$ & 19.6 & 18.2 & 18.3 & 18.7 \\
\hline & & Rainfall sum (mm) & 8.1 & 0.8 & 12.9 & 21.8 \\
\hline & \multirow[t]{2}{*}{ September } & Daily average air temperature $\left({ }^{\circ} \mathrm{C}\right)$ & 15.9 & 15.5 & 14.2 & 15.2 \\
\hline & & Rainfall sum (mm) & 22.7 & 0.0 & 2.8 & 25.5 \\
\hline
\end{tabular}

\section{RESULTS}

\section{Occurrence dynamics of $D$. virgifera} beetles in 2007-2009

In 2007 the first two beetles of Diabrotica virgifera were recorded on plants on 12 July, when the maize developed tassels (BBCH 55). That year the first individuals of both sexes occurred at the same time. A clear domination of males over females was only observed on 15 July, and later the females dominated. The maximum number of males was observed on 17 July (15 individuals/500 plants). In 2007 females were recorded from 12 July to 27 September, but males ended their flight very early, on $30 \mathrm{Au}-$ gust, when the plants were at the ripening dough stage (BBCH 85).

There was only one peak in the pest population size, observed on 24 July, when the plants were flowering 
(BBCH 67). During that period 80 beetles were recorded on 500 plants.

In 2007 the highest number of pests was recorded between 17 July and 14 August and this was determined by the dominating number of females. From among all the 553 cap- tured D. virgifera beetles, females accounted for $84.1 \%$ (465 individuals), while males accounted only for 15.9\% (88 individuals). The beetles ended their feeding in the third decade of September (Fig. 1).

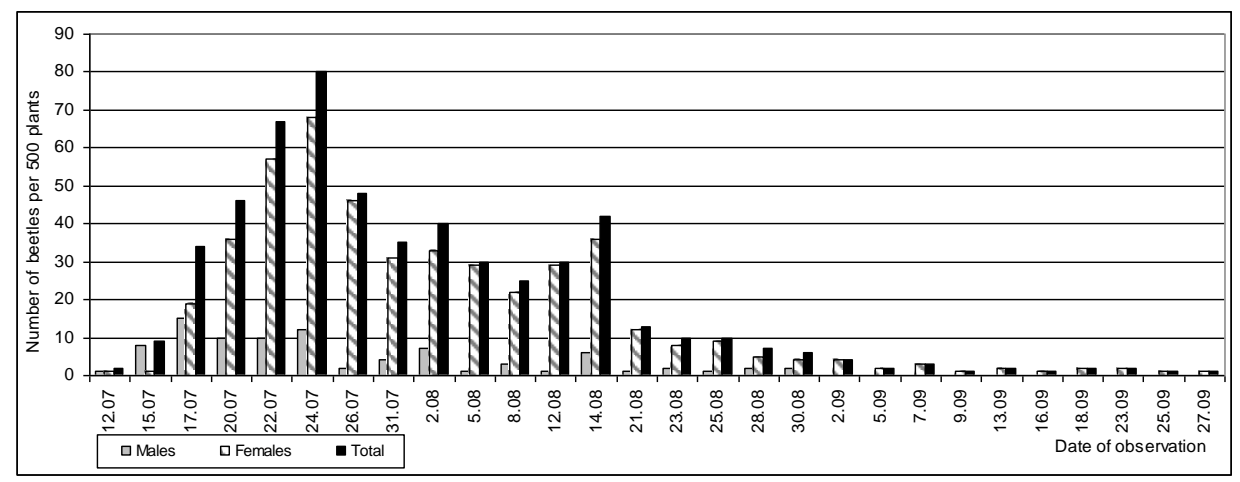

Fig. 1. Occurrence dynamics of Diabrotica virgifera beetles on sweet maize in 2007

In 2008, similar to the previous year, adult of $D$. virgifera began flying out of the pupa at the beginning of the second decade of July. The first recorded beetle was male (on 14 July), when maize was at stage 53 (tassel top visible). The first female occurred a week later, i.e. on 23 July. Initially, male individuals clearly dominated among the captured beetles and their number was higher than females until 6 August. The maximum number of males in that year was observed on 30 July (56 individuals/500 plants). From 9 August the number of females was higher and they were recorded on plants until 22 September. In comparison to 2007, the occurrence of males on plants was insignificantly longer and ended on 6 September.

Moreover, detailed observations also demonstrated that juvenile colourless beetles of $D$. virgifera, which had just left the pupa, were present on maize plants until the end of August. This indicates that the development of larvae, and the flight of adult is chronologically distributed.

In 2008 two peaks in the population size of beetles on plants were recorded. The first peak was observed on $30 \mathrm{July}$, and the second on $2 \mathrm{Au}-$ gust, when maize was at stage 71-73 (milky ripening stage of kernels). Both during the first and second population peak 70 individuals were captured on 500 plants. The first population peak was dominated by more numerous males, and the second by both sexes in total.

In that study year the period of the most numerous occurrence of beetles on plants was between 28 July and 23 August, and the last individual (female) was captured at the beginning of the third decade of September. In total, in 2008, during the entire maize vegetation season 776 WCR 
beetles were captured. In the total collected biological material females accounted for $59.7 \%$ (462 individu- als), while males accounted for $40.3 \%$

(314 individuals) (Fig. 2).

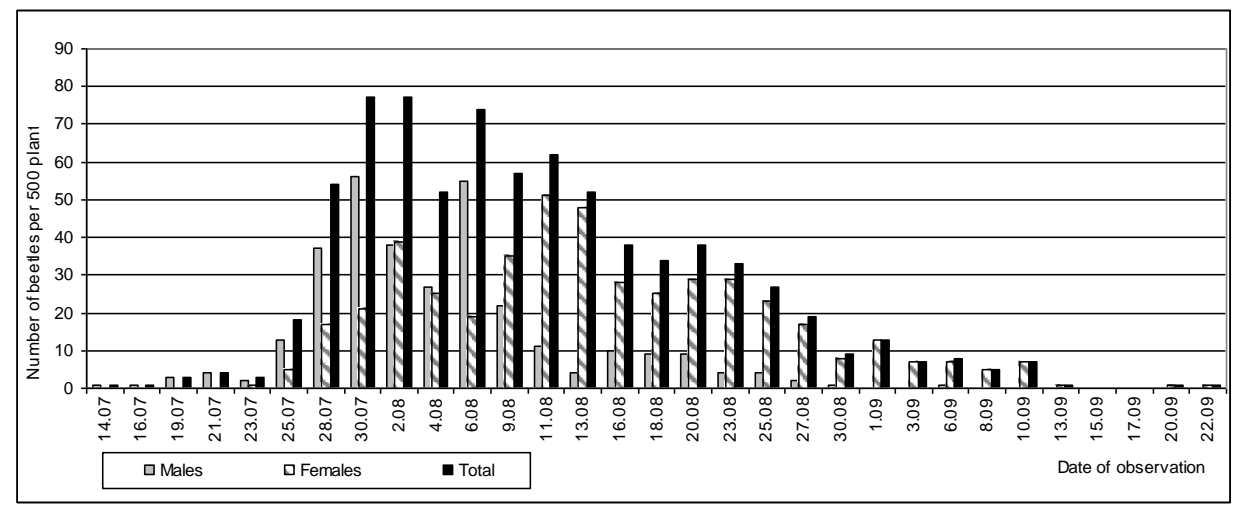

Fig. 2. Occurrence dynamics of Diabrotica virgifera beetles on sweet maize in 2008

In 2009 flights of WCR beetles began on 14 July, when maize was at stage 53. Two males occurred at first. Over the following days their number gradually increased, but the clear domination of males over females was maintained only until 26 July. The maximum number of males was observed on 7 August (38 individuals/500 plants). The first female occurred on 17 July and from that moment their number increased to reach the maximum population in the second decade of August. In comparison to previous years, the flight of males was long and ended on 23 September.

Similar to 2008, it was observed that in a monoculture cultivation the flights of beetles from pupa are chronologically distributed, because juvenile individuals were recorded on plants until the end of August.
In 2009 the period of the most numerous occurrence of beetles on maize was recorded from 28 July to 30 August, with the maximum of their population on 7 August (99 individuals on 500 plants), when maize was at stage 71-73. The population peak of beetles on plants, similar to previous years, was determined by more numerous females.

D. virgifera beetles ended feeding on plants in the third decade of September. The last captured individual was female (1 individual, on 29 September), when maize was at stage 89 .

In 2009 a total number of 952 WCR beetles were captured. Females were the dominant sex and they accounted for $72.4 \%$ (689 individuals), while males for $27.6 \%$ (263 individuals) (Fig. 3). 


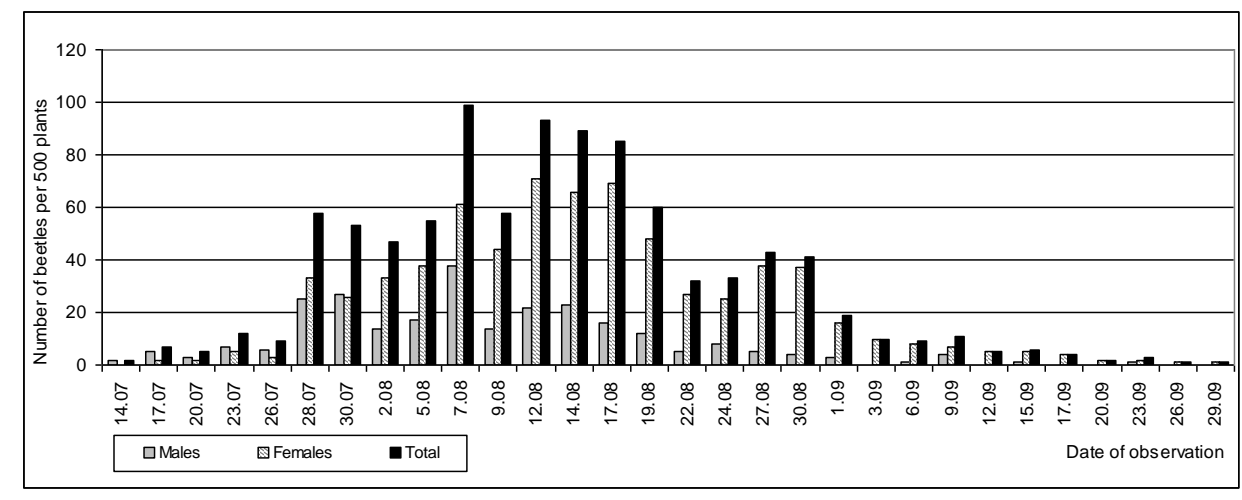

Fig. 3. Occurrence dynamics of Diabrotica virgifera beetles on sweet maize in 2009

\section{DISCUSSION}

In the conducted study on the dynamics of occurrence of western corn rootworm (WCR) (Diabrotica virgifera Le Conte) beetles on sweet corn the pheromone traps were used only in order to identify the time at which plant observations should be carried out, and then removed from the field. At a low abundance of adult individuals the use of pheromone traps allows for highly precise identification of the time of first beetle occurrence. However, to achieve a reliable result in capturing by using such equipment, suitable traps should be chosen and placed in the field at a suitable time. According to Bereś et al. (2009) during the maize vegetation season researchers should know the best time when the traps luring males (with sexual attractant) and individuals of both sexes (with food attractant) should be installed, as this determines the effect of the conducted monitoring and the number of captured beetles.

Another method used for the monitoring of the occurrence of WCR beetles involves the direct observation of maize plants (Chiang 1973). Such observations are only useful on maize cultivations in which the pest population is abundant. In this study the authors decided to use the method in question because the pest population was abundant enough to allow for direct collection of insects from maize plants. Furthermore, this method allows for the precise identification of sexual structure. This fact was essential, especially with respect to fertilized females which, having a large abdomen filled with eggs, practically lost their ability of flight and migrated between plants using their limbs. These females could not have been captured in pheromone traps with sexual attractant as their mobility was largely limited.

Based on the observation of plant and beetle capture the authors found that Diabrotica virgifera individuals in the south-eastern part of Poland occurred in cultivations of sweet corn from the second decade of July. In comparison to the studies carried out in the same location by Bereś and Sionek (2007), who in 2006 recorded the first individuals of $D$. virgifera on 26 July, in this study the first beetles occurred earlier. This may 
indicate that the pest population infesting the study area became gradually stabilized, which was not found in 2006, this being the second year of WCR occurrence in this part of Poland (Konefat et al. 2007). The time in which the first beetles occurred in early July is comparable to that observed by other authors, like Tančic et al. (2006) in Serbia and Darnell et al. (2000) in the USA. However, no adult individuals of the WCR were found on maize at the end of June, in contrast to reports by, for example Bača et al. (1995), Imrei et al. (2001), Pălăgesiu et al. (2001) and Ciobanu et al. (2007).

Observations from this study demonstrated that male individuals occur at first, and the flights of females begin several days later, which was confirmed in the studies by Imrei et al. (2001), Grozea and Lauer (2004) and Darnell et al. (2000). Moreover, it was found that the maximum number of males on plants was recorded earlier than that of females, which was also confirmed by Darnell et al. (2000).

It was found that during the feeding of beetles on maize the period of their most abundant occurrence was from the end of July until the third decade of August. Observations from this study confirmed the findings from the studies by Pălăgesiu et al. (2001) carried out in Romania, which demonstrated that the period of the most abundant occurrence of beetles is between the third decade of July and the third decade of August. The period of the maximum population size of adult $D$. virgifera individuals near Rzeszów was slightly longer than that observed in Serbia by Tančic et al. (2006), who found that the time of the most abundant occurrence of adult was between 30 July and 12 August, with the peak on 6 August. In this study the population peak for beetles was recorded in the third decade of July and the first decade of August. In studies by Bayar et al. (2003) conducted in Hungary, the peak of the beetle population was observed from the first to the third week of July.

The last individuals were recorded on plants in late September. Other authors also indicated that the beetles' flight ends in September or in October (Pălăgesiu et al. 2001, Boriani et al. 2006, Tančic et al. 2006, Ciobanu et al. 2007, Drzewiecki \& Pietryga 2009, Bereś et al. 2009).

Considering the ability of chemical control of $D$. virgifera beetles on sweet maize based on the studies on their occurrence dynamics it can be concluded that interventions for plant protection should be carried out during mass pest occurrence. In the conducted studies the best moment for chemical control interventions was between the last decade of July and the last decade of August. Because chemical control is mainly focused on the reduction of the number of fertilized females which, by depositing eggs, will give a start to a new generation, it should be applied during their population peak.

\section{CONCLUSIONS}

1. In the study years D. virgifera beetles began their flights onto sweet maize plants from the second decade of July and ended in the third decade of September.

2. The highest number of beetles was observed from the third decade of 
July to the second decade of August, with the population peak in the third decade of July or the first decade of August.

3. Usually males occurred on plants first, followed by females after a few days. The peak in the number of males was observed earlier than that of females, and the period of their occurrence on plants was shorter than that of females.

4. Females dominated among the captured insects during the study years. Their percentage share in the total number of captured beetles was from 59.7 to $84.1 \%$. The population of males in individual years varied, and their percentage share was between 15.9 and $40.3 \%$.

\section{REFERENCES}

Adamczewski K., Matysiak K. 2002. Klucz do określania faz rozwojowych roślin jedno- i dwuliściennych $\mathrm{w}$ skali $\mathrm{BBCH}$ [thumaczenie $\mathrm{i}$ adaptacja - K. Adamczewski, K. Matysiak]. Instytut Ochrony Roślin, Państwowa Inspekcja Ochrony Roślin i Nasiennictwa: 20-21. [in Polish]

Bača F. 1994. New member of the harmful entomofauna of Yugoslavia Diabrotica virgifera virgifera LeConte (Coleoptera, Chrysomelidae). Zaštita Bilja 45: 125-131.

Bača F., Camprag D., Keresi T., Krnjajic S., Manojlovic B., Sekulic R., Sicev I. 1995. [Western corn rootworm Diabrotica virgifera virgifera]. In: Drustvo za Zastitu Bilja Srbije. Belgrade, 1-112. [in Serbian with English summary]

Bayar K., Komáromi J., Kiss J., Edwards C.R., Hatala-Zsellér I., Széll E. 2003. [Characteristics of a population of western corn rootworm
(Diabrotica virgifera Le Conte) in continous maize.] Növénytermelés, 52: 185-202. [in Hungarian with English summary]

Bereś P.K., Sionek R. 2007. [Preliminary observations on western corn rootworm (Diabrotica virgifera Le Conte) biology in Rzeszow area]. Prog. Plant Protection/Post. Ochr. Roślin 47 (1): 188-193. [in Polish with English summary]

Bereś P.K., Kaniuczak Z., Sionek R. 2009. [Analysis of Diabrotica virgifera Le Conte beetles invasion of maize crops in Podkarpackie region based on pheromone and food trap catching in the 2006-2008]. Prog. Plant Protection/Post. Ochr. Roślin. 49(1): 86-90. [in Polish with English summary]

Boriani M., Agnosti M., Kiss J., Edwards C.R. 2006. Sustainable management of the western corn rootworm, Diabrotica virgifera Le Conte (Coleoptera: Chrysomelidae), in infested areas: experiences in Italy, Hungary and the USA. OEPP/EPPO Bull. 36: 531-537.

Chiang H.C. 1973. Bionomics of the northern and western corn rootworm. Annu. Rev. Entomol. 18: 47-72.

Ciobanu C., Sandor M., Domuta C., Ciobanu C., Albu R., Vuscan A. 2007. Life cycle of Diabrotica virgifera virgifera in the conditions from north-western part of the country. Annale Universitătii din Oradea, Fascicula: Protectia Mediului, Romania, 12: 1-8.

Ciosi M., Miller N.J., Kim K.S., Giordano R., Estoup A., Guillemaud T. 2008. Invasion of Europe by the western corn rootworm, Diabrotica virgifera virgifera: multiple transatlantic introductions with various reductions of genetic diversity. Molecular Ecology 17: 3614-3627.

Darnell S.J., Meinke L.J., Young L.J. 2000. Influence of corn phenology on adult western corn rootworm 
(Coleoptera: Chrysomelidae) distribution. Environ. Entomol. 29: $587-$ 595.

Drzewiecki S., Pietryga J. 2009. [Occurrence of western corn rootworm (Diabrotica virgifera Le Conte) in the south-western part of Poland]. Prog. Plant. Protection/Post. Ochr. Roślin 49 (4): 1681-1685. [in Polish with English summary]

EPPO Standards, European and Mediterranean Plant Protection Organization. 2004. Diagnostic protocols for regulated pests. Diabrotica virgifera. PM 7/36(1). Bull. OEPP/EPPO, 34: 289-293.

EPPO, European and Mediterranean Plant Protection Organization. 2010. Present situation of Diabrotica virgifera in Europe (2009). http://www.eppo.org/QUARANTIN E/Diabrotica_virgifera/diabrotica_vi rgifera.htm

Grozea I., Lauer K.F. 2004. Development of Diabrotica virgifera virgifera Le Conte adults in western plain conditions from Romania. Abstracts in IWGO Newsletter 25 (2), p. 9.

Imrei Z., Tóth M., Vörös G., Szarukán I., Gazdag T., Szeredi A. 2001. Comparison of performance of different trap types for monitoring of Diabrotica virgifera. p. 39-45. In: Proceedings XXI IWGO Conference, VIII Diabrotica Subgroup Meeting, Padva, Italy, 27 October-3 November, Italy. $438 \mathrm{pp}$.

Konefał T., Bereś P.K. 2009. Diabrotica virgifera Le Conte in Poland in 2005-2007 and regulations in the control of the pest in 2008. J. Plant Protection Res. 49 (1): 129-134.
Konefał T., Buzon D., Bereś P.K. 2007. [The second year of presence of Diabrotica virgifera Le Conte in Poland - actual situation and new experiences in control of the pest]. Prog. Plant Protection/Post. Ochr. Roślin 47 (1): 256-262. [in Polish with English summary]

Krysan J.L., Smith R.F. 1987. Systematics of the virgifera species group of Diabrotica (Coleoptera: Chrysomelidae: Galerucinae). Entomography 5: 375-484.

Pălăgesiu I., Grozea I., Hâncu M. 2001. Evolution of the pest Diabrotica virgifera virgifera Le Conte in the Timis district. p. 139-149. In: Proceedings XXI IWGO Conference, VIII Diabrotica Subgroup Meeting, Padva, Italy, 27 October-3 November, Italy. $438 \mathrm{pp}$.

Sahajdak A., Bereś P.K., Konefał T. 2006a. Diabrotica virgifera Le Conte - a new threat to maize crops in Poland and measures taken against the pest. J. Plant Prot. Res. 46 (2): 157-161.

Sahajdak A., Bereś P., Uznańska B., Konefał T. 2006b. [Western corn rootworm - a new threat to maize crops in Poland]. Prog. Plant Protection/Post. Ochr. Roślin 46 (1): 256261. [in Polish with English summary]

Tančic S., Bača F., Gošic Dondo S. 2006. Sesonal dynamics of the Diabrotica virgifera virgifera Le Conte (Coleoptera: Chrysomelidae) in Zemun Polje (Serbia). Acta. Entomol. Serbica 11 (1/2): 45-50. 


\section{WYSTĘPOWANIE I STRUKTURA PŁCIOWA CHRZĄSZCZY \\ DIABROTICA VIRGIFERA LE CONTE NA KUKURYDZY CUKROWEJ \\ (ZEA MAYS VAR. SACCHARATA) W POLUDNIOWO-WSCHODNIEJ POLSCE \\ W LATACH 2007-2009}

\section{Streszczenie}

Badania wykonano w latach 2007-2009 w Terliczce koło Rzeszowa na kukurydzy cukrowej (Zea mays var. saccharata) odmiany Candle. Obserwacje prowadzono w oparciu o pozwolenie Głównego Inspektora Ochrony Roślin i Nasiennictwa nr WF$411 \mathrm{~d} / 5 / 2008$

Celem wykonanych badań było wyznaczenie dynamiki występowania chrząszczy Diabrotica virgifera na kukurydzy cukrowej dla potrzeb określenia optymalnego terminu ich zwalczania. Ponadto określono ich strukturę płciową w okresie od lipca do września.

W południowo-wschodniej Polsce chrząszcze D. virgifera zaczęły nalatywać na rośliny kukurydzy cukrowej od drugiej dekady lipca. Jako pierwsze pojawiały się zwykle osobniki męskie, a dopiero po kilku dniach rozpoczynały się naloty samic. Stwierdzono ponadto, że maksimum występowania samców na roślinach przypada wcześniej aniżeli samic.

W trakcie żerowania chrząszczy na kukurydzy stwierdzono, że okres najliczniejszego ich występowania przypadał od końca lipca do trzeciej dekady sierpnia. W okresie lotu osobników dorosłych stwierdzono występowanie zwykle jednego szczytu nasilenia ich występowania, który miał miejsce w III dekadzie lipca oraz w I dekadzie sierpnia, a jedynie w 2007 roku wystąpił w II dekadzie lipca. W latach 2007-2009 chrząszcze $D$. virgifera kończyły swoje żerowanie pod koniec września.

W okresie badań płcią dominującą w odłowach były samice. Procentowy udział w ogólnej liczbie złapanych chrząszczy wynosił od 59,7 do 84,1\%. Liczebność samców w poszczególnych latach była zmienna, a procentowy udział kształtował się pomiędzy 15,9 a $40,3 \%$. 